\title{
8-ヒドロキシキノリンによるヒドロキシウレアの比色測定
}

\author{
大村 浩 久*, 鳥巣隆 雄**, 篠原 和 毅*, 飯 尾 雅 嘉* \\ * 九州大学農学部食糧化学教室 \\ **大日本インキ化学工業株式会社
}

\section{Colorimetric Determination of Hydroxyurea with 8-Hydroxyquinoline}

\author{
Hirohisa Omura*, Takao Tosu**, Kazuki Shinohara*, Masayoshi Iio* \\ *Food Chemistry Institute, Faculty of Agriculture, Kyushu University, Hakozaki, Fukuoka \\ **Dainippon Ink Chem. Eng. Co., Ichihara, Chiba
}

J. Jap. Soc. Food and Nutr., 24(7), 382 387 (1971)

\begin{abstract}
Hydroxyurea is tentatively suggested to be one of the most reasonable reaction product from urea by urea dehydrog nnase. Bacause hydroxyurea has been colorimetrically estimated with $p$-dimethylamino. benzaldehyde as urea or its derivatives, a procedure for independent estimation of the former from the latters has been required. It was observed that hydroxyurea turns yellowish green with 8-hydroxy. quinoline similar to hydroxylamine, while urea and its derivatives not. In the absorption spectrum of the colored solution of hydroxyurea, a peak is observed at $425 \mathrm{~m} \mu$ and no absorption over about $600 \mathrm{~m} \mu$. On the other hand, in the case of hydroxylamine, the main peak at $710 \mathrm{~m} \mu$ and the second one at $425 \mathrm{~m} \mu$ are determined. By discussing some conditions such as buffers, sodium carbonate, coloring temperature and time, the method was established as follows for colorimetry of hydroxyurea, by which urea and its derivatives can not be determined. A mixture of $1 \mathrm{~m} l$ hydroxyurea, $1 \mathrm{~m} l 0.2 \mathrm{M}$ Tris buffer $(\mathrm{pH} 7.5), 1 \mathrm{~m} l$ $1 \%$ 8-hydroxyquinoline, $1 \mathrm{ml} 1 \mathrm{M} \mathrm{Na}_{2} \mathrm{CO}_{3}$ and $\mathrm{H}_{2} \mathrm{O}$ to be $5 \mathrm{ml}$ of total volume was incubated at $40^{\circ} \mathrm{C}$ for 3 hours and the optical density was estimated at $425 \mathrm{~m} \mu$. The absorbancy is proportional to concen. tration of hydroxyurea in a range between $5 \times 10^{-5} \mathrm{M}$ and $10^{-3} \mathrm{M}$.

However, because similar and much intensive coloration was brought about by hydroxylamine, estimation of hydroxyurea was disturbed, although the colorimetry of hydroxylamine was not interferred by hydroxyurea. In addition, similar coloration was observed with several substances such as phenyl. hydrazine, semicarbazide and others, which also disturb the estimation of hydroxyurea.
\end{abstract}

(Received June 28, 1971)

近年ヒドロキシウレアがたとえば DNA の合成を特異 的阻害するものとしてその機能が注目され，ウイルス や癌に関連してそれらの研究に広く利用されるようにな ってきだ 〜3)。このヒドロキシウレアが食糧成分として 存在しているか否かは確められていないが，それが生物 組織に含まれるという可能性を全く無視することはでき

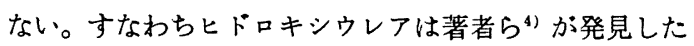
尿素脱水素酵素の反応生成物の有力な一つであるとい5 ことは理論的に推定される。著者らは前報》においてこ のような観点からヒドロキシウレアの諸性質について検 討し, とくにカタラーゼやウレアーゼに対する阻害作用 やその化学構造などとも関連して無機窒素代謝系に扣け
るヒドロキシルアミンに相当するすのと推定した。この ヒドロキシルアミンは食䊓の無機窒索成分の一つとして 確認され,さらにウイルスや突然変異の誘発をはじめ種 々の興味ある機能か著者らの研究室に扣いて広く研究さ れてきだ)。しかし現在までの所ヒドロキシルフミンは 主としてオキシムのような結合型として生体組織中に存 在し, しかもその量も少ないのでほとんど問題にはなっ ていないわ。いずれにしてもヒドロキシウレアがヒドロ キシルアミンと同じょうな位置にあるとすれば, 同様な 問題は十分に検討しておく必要があり，食糧成分である か否かを確認する目的ともあわせてすぐれた測定法の確 立が望まれるのは当然である。 
前報》です述べたようにこのヒドロキシウレアは メチルアミノベンズアルデヒドと反応して黄色を呈する ので $420 \mathrm{~m} \mu$ の吸光度を求めることによって測定される。 しかしこの呈色反応は広く尿素誘導体に共通して示され るので(日), これらとの分離定量には利用できず, 従って 食糧成分としての確認および，とくに尿素脱水素醭素の 反応液などには適用されない。

一方著者らの研究室において無機窒素代謝の研究に際 し8ーヒドロキシキノリンによるヒドロキシルアミンの比 色定量法を確立した ${ }^{10) 11) 。 こ れ は ヒ ト ゙ ロ キ シ ル ア ミ ン か ゙ ~}$ 8-ヒドロキシキノリンと反応して緑色のインドキシンを 生成する反応 ${ }^{12}$ を利用したものであって, 西硝酸や次互 硝酸が共存してもそれらに影響されずしかも鋭敏なすぐ れた方法である。著者らはヒドロキシウレアすこの試薬 と反応して黄緑色を呈するが尿素は発色しないことをみ いだしたのでこの反応をヒドロキシウレフの测定に利 用するためその条件を検討した。

\section{実 験 方 法}

\section{1. 吸収スペクトルおよひ吸光度の测定}

吸収スペクトルは既述の方法 ${ }^{13)}$ に従い島津マルチパー パス自記分光光度計 MPS-50 型て測定し, 一方吸光度 は主として日立分光光度㖕 EPU-2 型で常法により求 めた。

\section{2. 試薬}

1）ヒドロキシウレア 前報5) 記載の方法によってヒ ドロキシルアミンから合成し $5 \sim 6$ 回再結した。これに はヒドロシルアミンの混在は認められなかった。

2）8-ヒドロキシキノリン溶液 8-ヒドロキシキノリ ン $1 \mathrm{~g}$ をアルュール $100 \mathrm{~m} l$ に溶解した。

3）トリス緩衝液 $0.2 \mathrm{M}, \mathrm{pH} 7.5$ のトリス塩酸溶液

4）炭酸ナトリウム溶液 $1 \mathrm{M}$ 水溶夜

\section{3. 呈色法}

試料 $1 \sim 2 \mathrm{~m} l$ にトリス緩衝夜 $1 \mathrm{~m} l, 8$-ヒドロキシキ ノリン溶液 $1 \mathrm{~m} l$ 扣よび炭酸ナトリウム溶液 $1 \mathrm{~m} l$ を加え （水により全量 $5 \mathrm{ml}$ とし）よく振盪混合して発色させ たのちその吸光度を測定する。なお対照には試料を加え ないすのを用いる。この際ヒドロキシルアミン10)11につ いては室温に60分間放置して発色させ， $700 \mathrm{~m} \mu て ゙$ 吸光度 を求めた。

\section{実験結果および考察}

\section{1. 呈色液の吸収スペクトル}

$5 \times 10^{-3} \mathrm{M}$ ヒドロキシウレア溶液を原法によって発色 させその可視部における吸収スペクトルを図1 1 示す。

これから明らかなように呈色液の吸収スペクトルは 425 $\mathrm{m} \mu \sim 430 \mathrm{~m} \mu$ 付近に吸収極大を示し，これより長波長側

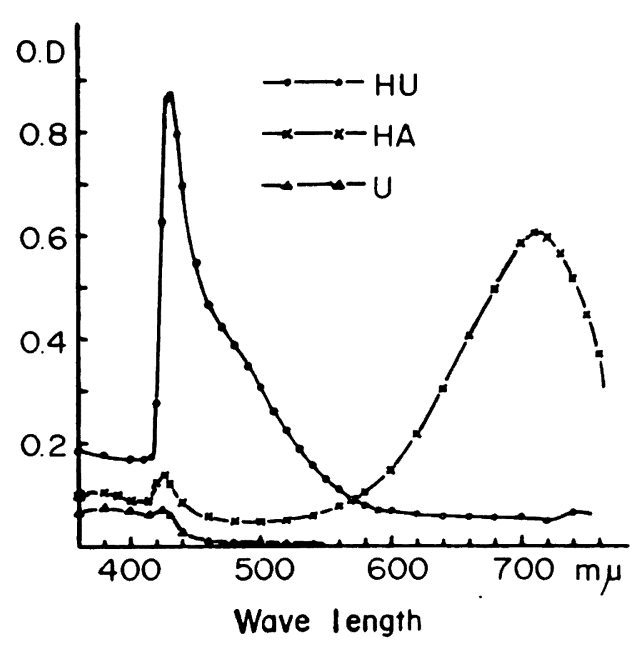

Fig. 1. Absorption spectra of the colored solution of hydroxyurea, urea and hydroxylamine with 8 -hydroxyqu. inoline.

A mixture of $1 \mathrm{ml} 5 \times 10^{-3} \mathrm{M}$ hydorxyurea (HU), $5 \times 10^{-4} \mathrm{M}$ hydroxylamine (HA) or $10^{-1} \mathrm{M}$ urea (U), $1 \mathrm{ml} 0.2 \mathrm{M}$ Tris buffer ( $\mathrm{pH} 7.5), 1 \mathrm{ml} 1 \%$ 8-hydroxyquinoline, $1 \mathrm{~m} l 1 \mathrm{M} \mathrm{Na} \mathrm{CO}_{3}$ and $1 \mathrm{~m} l$ $\mathrm{H}_{2} \mathrm{O}$ was incubated at room temperature for 60 minutes.

に移るに従って吸光庭は減少し $600 \mathrm{~m} \mu$ 付近以上ではほ とんと吸収を示さない。これに対して尿素ではほとんど 発色せず， $0.1 \mathrm{M}$ 溶液に拈いても $430 \mathrm{~m} \mu$ 付近にわずかに 極大がある傾向は認められるにしても, その吸光値は無 視して差支えない。従ってこの呈色反応によってヒドロ キシウレアは尿素が共存しても測定できる可能性は考え られる。

元来本法はヒドロキシルアミンの測定のために改良さ れたものである。しかもヒドロキシウレアは一般に不安 定であってヒドロキシルアミンを生成するといわれてい る。しかし同じ試薬によるヒドロキシルアミン呈色液の 吸収スペクトルには $710 \mathrm{~m} \mu$ 付近に強い極大があり,さ らに $425 \mathrm{~m} \mu$ 付近にも第 2 の吸収が観察され, ヒドロキ シウレアの発色機構は明らかでないが少なくともヒドロ キシルアミンを経て発色するといら推定は否定される。 しかもヒドロキシルアミンの呈色は鋭敏であって発色度 はヒドロキシウレアのほぼ10倍にも達し, 前者による $425 \mathrm{~m} \mu$ の吸収は無視できない。因 1 の吸収スペクトルは $5 \times 10^{-4} \mathrm{M}$ ヒドロキシルアミンを呈色させたものである。 従ってこの両者が共存する場合にはヒドロキシウレアの 測定はさらに検討しなければならない。これに対して上 述のよ5にヒドロキシウレア呈色液の吸光度は $600 \mathrm{~m} \mu$ 付近以上ではほとんど認められないので $700 \mathrm{~m} \mu$ で吸光 度を測定するヒドロキシルアミンの定量には支障はな 
Table 1. Effect of some buffers on coloration

\begin{tabular}{llllllllll}
\hline Buffer & None & \multicolumn{3}{c}{ Tris-HCl } & \multicolumn{3}{c}{ Phosphate } & \multicolumn{3}{c}{ Acetate } & Veronal \\
\hline $\mathrm{pH}$ & & 7.0 & 7.5 & 8.0 & 7.0 & 7.5 & 8.0 & 7.5 & 7.5 \\
$\mathrm{OD}_{425}$ & 0.770 & 0.790 & 0.850 & 0.770 & 0.595 & 0.680 & 0.660 & 0.680 & 0.720 \\
\hline
\end{tabular}

The same as in Fig. 1 with different buffer and the optical density was estimated at $425 \mathrm{~m} \mu$.

い。

\section{2. 测定条件の検討}

1）緩衝液 8-ヒドロキシキノリンによるヒドロキシ ルアミンの定量法は元来 Magee 扰よび Burrisis)によ って報告されたすのであるが，筬島 ${ }^{10)}$ はこの呈色がトリ ス緩衝液の添加によって著しく增大しそれにといなって 精度も向上寸るが, 醉素反応などに通常利用されている 酷酸緩衝液，リン酸緩衝液，ベロナール緩衝液などによ っては何ら影響されないことを認めた。そこでヒドロキ シウレアの呈色についてもこれら緩衝液の影響をまず同 㥞に検討した。

表 1 から明らかなようにヒドロキシウレアの呈色もヒ ドロキシルアミンの場合と同彔にトリス緩衝液によって 增強された。しかしリン酸または酢酸緩衝液によっては かえって発色は低下し，これらによっていほとんど影響 されないヒドロキシルアミンとは巽なった。また $\mathrm{pH} の$ 影響もヒドロキシルアミンではそれほど著しくはなく 7.0ないし7.5でほほ同一の吸光度を示すが，ヒドロキシ ウレアでは $\mathrm{pH} 7.5$ で最も大きい值を示し $\mathrm{pH}$ の条件む かなりきびしかった。その機棈淜らかでないが，いず れにしてもトリス緩衝液の添加によって呈色度が高めら れ, しかも pH 7.5 のものが最も望ましいことが明らか になった。

この緩衝液を呈色倵螺つ一種として使用する時の添加 量について検した。その結果因 2 に示すよ5にヒドロ キシウレアの呈色もヒドロキシルアミンの場合と同様に $0.2 \mathrm{M}$ トリス緩衝液を $0.75 \mathrm{~m} l$ 如えた時にほぼ最高に達し それ以上で虫一定であった。従って多少の余裕をみて1 $\mathrm{m} l$ 加充れば十分である。

2）炭酸ナトリウムつきに炭酸ナトリウムの所要量 を求めた。図3から明らかなよ5にトリス緩㣫液の他 に炭酸ナトリウムの添加も必要であり，しかも $1 \mathrm{M}$ 溶液 0. $75 \mathrm{~m} l$ 以上加えた場合に吸光湾は一定となった。従っ てこの場合にもヒドロキシルアミンの残々同䈋に多少の 安全度を見込んで $1 \mathrm{ml}$ 加えることとした。

3）温度扰よび時間 また種々の温度での発色を図 4 に示す。これからわかるよ $5 に 50^{\circ} \mathrm{C}$ 以上であれば呈色 はほとんど一定となり，しかも時間の影響もほとんど認 められない。しかし盲桧值も大きくなるし，また温度保 持上にも好ましいものではない。従って精度は多少少っ

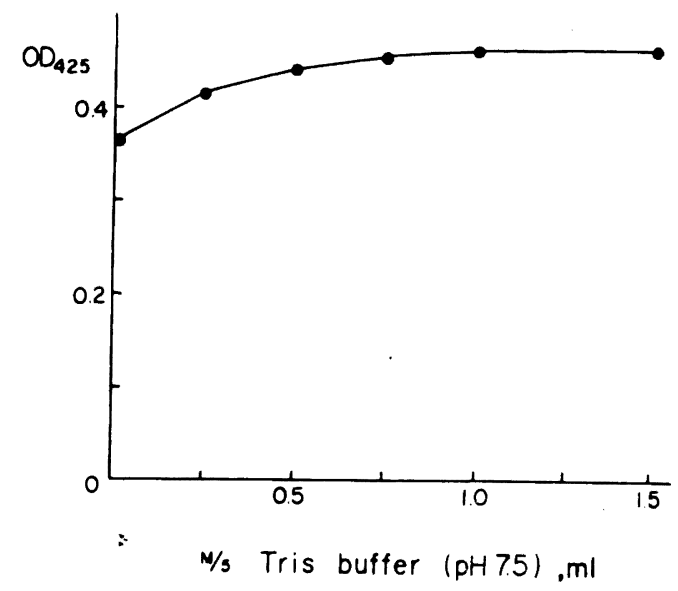

Fig. 2. Effect of Tris buffer on coloration. Reaction mixture: $5 \times 10^{-3} \mathrm{M}$ hydroxyurea $1 \mathrm{~m} l$, $0.2 \mathrm{M}$ Tris buffer $0 \sim 1.5 \mathrm{ml}, 1 \mathrm{M} \mathrm{Na} \mathrm{CO}_{3} 1 \mathrm{~m} l$, 8 -hydroxyquinoline $1 \mathrm{ml}, \mathrm{H}_{2} \mathrm{O} 2 \sim 0.5 \mathrm{ml}$. The optical density was estimated at $425 \mathrm{~m} \mu$ after 60 minutes at room temperature.

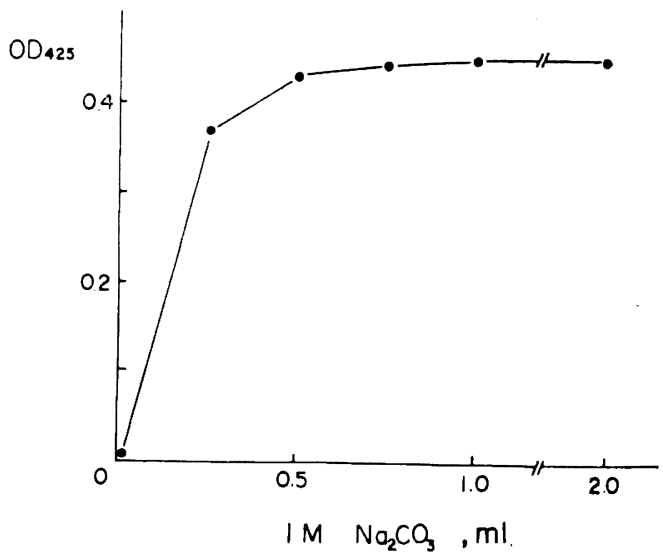

Fig. 3. Effect of sodium carbonate on coloration. Reaction mixture: $5 \times 10^{-3} \mathrm{M}$ hydroxyurea $1 \mathrm{ml}$, $0.2 \mathrm{M}$ Tris buffer $1 \mathrm{ml}, 1 \mathrm{M} \mathrm{Na} \mathrm{CO}_{3} 0 \sim 2 \mathrm{ml}$, 8hydroxyquinoline $1 \mathrm{ml}, \mathrm{H}_{2} \mathrm{O} 2 \sim 0 \mathrm{ml}$. The same as in Fig. 2.

ても $40^{\circ} \mathrm{C} て ゙$ 発色させた方が実際上都合がよいよ5に思 われた。ヒドロキシルアミンの場合呈色は $15^{\circ} \mathrm{C}$ 以上で 一定であって敩寒期以外は室温で差支えないのにくらべ ると操作上の不利は免れない。 


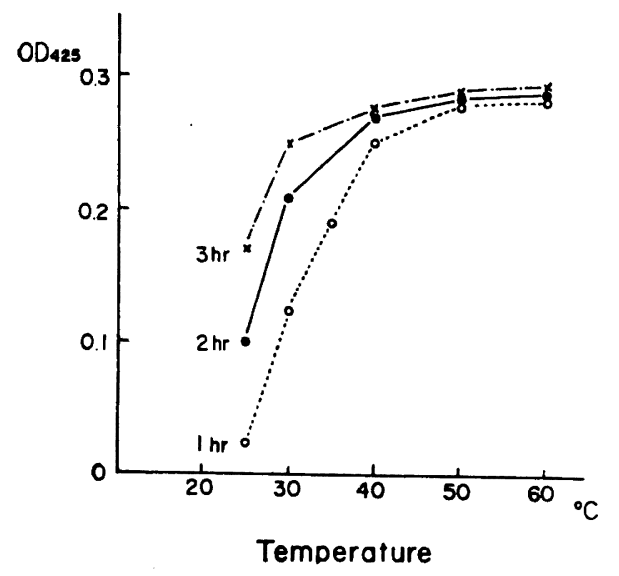

Fig. 4. Coloration at various temperature. The same as in Fig. 1, but the optical density was estimated at $425 \mathrm{~m} \mu$ after incubation at $25^{\circ} \sim 60^{\circ} \mathrm{C}$ for 1,2 or 3 hours.

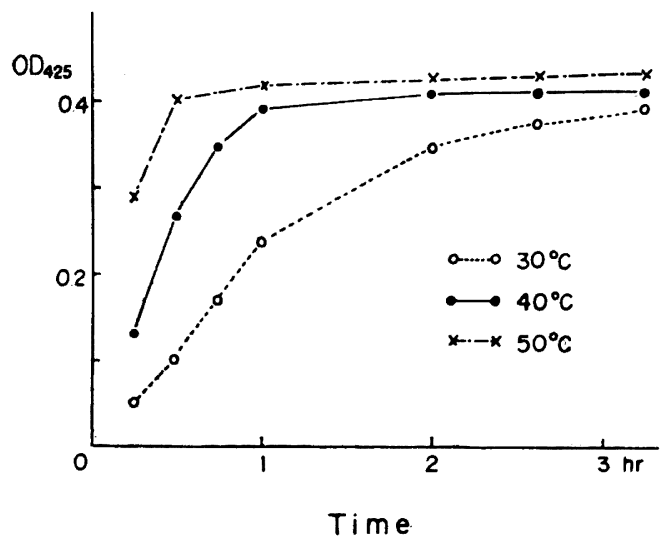

Fig. 5. Coloration for different time.

The same as in Fig. 1, but the optical density was estimated at $425 \mathrm{~m} \mu$ after incubation at $30^{\circ}, 40^{\circ}$ or $50^{\circ} \mathrm{C}$ for $15 \mathrm{~min} . \sim 3$ hours.

また試薬添加後 $30^{\circ} \mathrm{C}, 40^{\circ} \mathrm{C}$ および $50^{\circ} \mathrm{C} て ゙ の$ 時間に よる吸光度の增加を図 5 に示す。これから明らかなよう に! $50^{\circ} \mathrm{C}$ では呈色は 1 時間後に最大となり以後はほとん

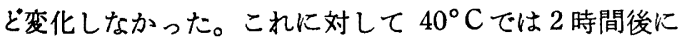
ほほ安定したが， $30^{\circ} \mathrm{C}$ ではさらに緩䝢であって 3 時間 後もな譄加する傾向を示した。従って呈色度は $40^{\circ} \mathrm{C}$ 3 時間後に求めることとした。これに対してヒドロキシ ルアミンでは上述のように室温でしかる反応時間は 1 時 間で十分である。

こらして最終的にヒドロキシウレアの場合には試験夜 $1 \mathrm{ml}$ に0.2Mトリス緩㣫液( $\mathrm{pH} 7.5) 1 \mathrm{ml}, 1 \% 8$ ヒド ロキシキノリン溶夜 $1 \mathrm{~m} l, 1 \mathrm{M}$ 炭酸ナトリゥム溶液 $1 \mathrm{~m} l$ を加光水で全量 $5 \mathrm{~m} l$ とし， $40^{\circ} \mathrm{C}$ に 3 時間放置して呈色

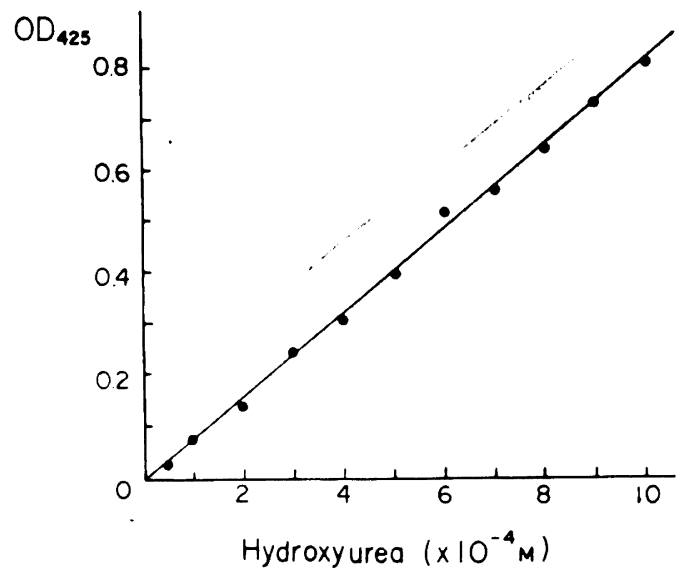

Fig. 6. Standard curve of hydroxyurea. A mixture of $1 \mathrm{~m} l$ hydroxyurea, $1 \mathrm{~m} l 0.2 \mathrm{M}$ Tris buffer ( $\mathrm{pH}$ 7.5), $1 \mathrm{ml} 1 \%$ 8-hydroxyquinoline, $1 \mathrm{ml} 1 \mathrm{M} \mathrm{Na}_{2} \mathrm{CO}_{3}$ and $\mathrm{H}_{2} \mathrm{O}$ to be $5 \mathrm{ml}$ total volume was incubated at $40^{\circ} \mathrm{C}$ for 3 hours and the optical density was estimated at $425 \mathrm{~m} \mu$ (under condition established for hydroxyurea).

させたのち $425 \mathrm{~m} \mu$ における吸光度を测定することとし た。種々の濃度のヒドロキシウレアの呈色を図 6 に示す

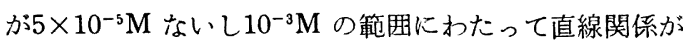
あることが確められた。

従ってこの方法はヒドロキシルアミンの場合と同一の 試薬を同一の割合で用いることができる利点がある。し かし高温長時間の発色条件性アミンょり不利である。い ずれにしても，この両者が共存する場合大きな欠点悗 れないが，ヒドロキシルアミンについては上述のように 問題はなく，一方ヒドロキシウレアについても次報敫に 示すよ5に実鏂的に解決することができた。

\section{3. 影䉪物質}

このようにして一応ヒドロキシウレアの比色定量のた めの条件が確立されたが他の物質の影響などもあらかじ め検討しておかなければならない。

1）酵素タン白 この研究の目的の一つは生物組織あ るいは酵素反応液中のヒドロキシウレアの定量法を確立 することにある。そこで㲾菜脱水素醅菜の反応液につい て試験した。窒素代謝の研究に批けるこれまでの経斯か ら植物性酵菜標品よりも動物性標品の影響が大きいので

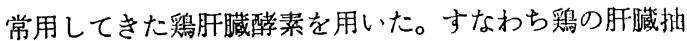
出液からアセトン分画によって粗醅素を調製した ${ }^{15)}$ 。種 々の濃度に溶かした醉素液 $1 \mathrm{ml}$ に $0.1 \% \mathrm{NAD} 0.5 \mathrm{ml}$, $0.2 \mathrm{M}$ トリス緩衙液 $(\mathrm{pH} 7.5) 0.5 \mathrm{~m} l, 10^{-3} \mathrm{M}$ 尿素 $1 \mathrm{~m} l$ および水 $1 \mathrm{~m} l$ を加えた反応液にヒドロキシウレア $1 \mathrm{~m} l$ を加え直ちに $10 \%$ トリクロール酢酸 $1 \mathrm{~m} l$ を加えて除夕 ン白した溶液について呈色度を求めた。その結果図 7 に 


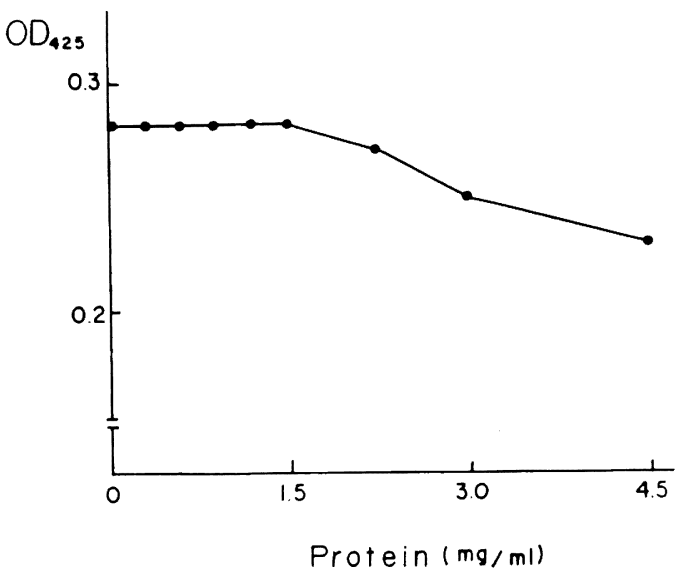

Fig. 7. Effect of the enzyme preparation on the coloration.

One $\mathrm{m} l$ of hydroxyurea was added to the reaction mixture of $1 \mathrm{~m} l$ fowl liver enzyme solution, $0.5 \mathrm{~m} l 0.1 \%$ NAD solution, $0.5 \mathrm{~m} l \quad 0.2 \mathrm{M}$ Tris buffer ( $\mathrm{pH} 7.5$ ), $1 \mathrm{ml} 10^{-3} \mathrm{M}$ urea and $1 \mathrm{ml} \mathrm{H}_{2} \mathrm{O}$ (for assay of urea dehydrogenase), and $1 \mathrm{ml} 10$ $\%$ trichloroacetic acid was added at once and centrifuged. For the supernatant, hydroxyurea was assayed as in Fig. 6.

示すよ 5 にタン白含量 $1.5 \mathrm{mg} / \mathrm{mll}$ 以内酵素液では上記 条件においてはその共存ならびに除タン白操作の影響は 無視される。しかしそれ以上の濃度のものではタン白含 量に従って, たとえば吸着などのために呈色度の低下が 認められた。

2）尿素関連物質およびオキシム 尿素脱水素酵素が 尿素の同化に関与寸ると推定されること,ならびに前 報5) で諭じたよ5にヒドロキシウレアの機能に $=\mathrm{N}-\mathrm{OH}$ 基の役制が考えられることから，泳素ならびにアルギニ

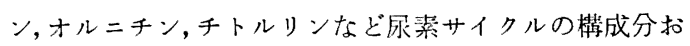
よび=N-OH 基を含むものとしてピルビン酸オキシムお よび $\alpha$ ケトグルタル酸オキシムの影響を試䜽したが，い

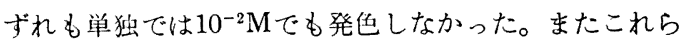
をヒドロキシウレアに加えた混合液の呈巴度はヒドロキ シウレア単独のものと一致し発色には影響しなかった。 従ってこの方法は尿素の同化に関する研究にはそのまま 利用できることが推定される。

3）妨害物質 上述のよ5に本法は元来ヒドロキシル アミンの定量法として開発されたものであって, ヒドロ キシウレアの呈色はヒドロキシルアミンの测定には差支 えないが逆にヒドロキシルフミンの呈色はヒドロキシウ レアの測定に大きく影響することは吸収スペクトルの比 較から既に指摘した。

さらにこの呈色法によりアンモニア, アルカリ, アル コール, ヒドラジンなどす程店の差はあるがそれぞれ単
Table 2. Coloration by several substances

\begin{tabular}{lcc}
\hline Compound & Conc. $\mathrm{M}$ & $\mathrm{OD}_{425}$ \\
\hline Hydroxyurea & $10^{-3}$ & 0.560 \\
$\mathrm{NH}_{4} \mathrm{OH}$ & $10^{-2}$ & 0.680 \\
$\mathrm{NaOH}$ & $10^{-2}$ & 0.265 \\
$\mathrm{KOH}$ & $10^{-2}$ & 0.120 \\
$\mathrm{CH}_{3} \mathrm{OH}$ & $99 \%$ & 0.360 \\
$\mathrm{C}_{2} \mathrm{H}_{5} \mathrm{OH}$ & $99 \%$ & 0.540 \\
Phenylhydrazine & $10^{-4}$ & 0.210 \\
Hydrazine & $10^{-2}$ & 0.080 \\
Semicarbazide & $10^{-4}$ & 0.100 \\
Isonicotinic acid hydrazide & $10^{-3}$ & 0.170 \\
Uric acid & $10^{-2}$ & 0.210 \\
Guanidine & $10^{-2}$ & 0.000 \\
Methylisourea & $10^{-2}$ & 0.000 \\
Phenylthiourea & $2.5 \times 10^{-2}$ & 0.025 \\
\hline
\end{tabular}

The same as in Fig. 6.

独で発色することが認められそれらの妨害が予想され る。表 2 から明らかなようにフェニルヒドラジンおよび セミカルバチドの呈色は顕著であってヒドロキシウレア のものよりも大きいことも本法の欠点ということができ る。とくにフェニルヒドラジンの呈色は著しく, しかも 次報 ${ }^{16)}$ に示すよ 5 に $490 \mathrm{~m} \mu$ 付近にさらに大きい吸収が 観察された。一方イソニュチン酸ヒドラチドの呈色す七 ドロキシウレアによるものよりは低いが無視されない。 しかしヒドラジンの呈色は微弱であった。また尿酸のほ かアンモニアやアルカリさらにはアルコールによっても 呈色しヒドロキシウレアの測定にあたってはその妨害を 考奀しなければならない。

こうして本定量法が尿素脱水素酵素の研究に適用でき ることは一応碓められたが，天然物の場合抽出法などの 検討がさらに必要であることは当然である。この場合こ れらの影響物質も考風されなければならない。しかし現 在までのところ天然物あるいは加工食品中にヒドロキシ ウレアの存在は確認されていないので, それが先決であ ろ5。

\section{要約}

8ーヒドロキシキノリンによりヒドロキシウレフは発色 し $425 \mathrm{~m} \mu$ に極大を示す吸収スペクトルが観察された。 この呈色反応に及ほす諸条件を検討しヒドロキシウレア の比色定量法を確立した。すなわら誠料 $1 \mathrm{ml} l$ に0.2Mト

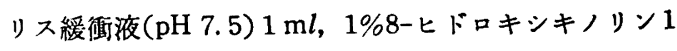
$\mathrm{ml}, 1 \mathrm{M}$ 炭酸ナトリウム $1 \mathrm{~m} l$ を加え水で全量 $5 \mathrm{ml}$ とし, $40^{\circ} \mathrm{C} 3$ 時間反応させたのち $425 \mathrm{~m} \mu$ における吸光度を 测定する。これによって吸光度は $5 \times 10^{-5} \mathrm{M}$ ないし10-3 Mの範囲にわたって濃度と直線関係が認められた。 
さらに尿素およびその誘導体は本法によって呈色せず これらとヒドロキシウレアとの分別定量が可能であるこ とが示された。しかしヒドロキシルアミンをはじめブェ ニルヒドラジン，セミカルバチド，その他の物質による 施害は免れなかった。

\section{文献}

1) Young, C. W. and Hodas, S. : Science, 146, 1172 (1964)

2 ) Bendich, A., Borenfreund, E., Korngold, G. C., Krim, M. and Balis, M. E.: Acidi nucleici e lero funzione biologica, Instituto Lombardo Fondazione Basselli, p. 214 (1964)

3) Yarbro, J. W.: Cancer Res., 28, 1082 (1968)

4) Omura, H. and Osajima, Y.: Nature, 190, 345 (1961)

5 ) 大村浩久, 塚本 徽, 篠原和毅, 鳥笨隆雄 : 栄養 と食糧，23，344 (1970)

6) Yamafuji, K.: Nutritional Factors in Virus
Formation, Crosby Lockwood, London (1964)

7) Yamafuji, K., Kondo, H. and Omura, H.: Enzymologia, 14, 153 (1950)

8 ）足立 達: 科学, 23,582 (1953)

9 ）大村浩久, 小野泰道, 水上浩明: 九大農学芸誌, 22,325 (1966)

10）放島 豊: 九大農学芸誌， 18, 271 (1961)

11）大村浩久，笛島 豊，波多野昌二，吉原典子，渡 辺健治, 山藤一雄：九大農学芸誌, 20,179(1963)

12) Berg, R. and Becker, E.: Ber. Deutsch. Chem. Ges., 73 B, 172 (1940)

13) 大村浩久, 内田 泰, 㬝田民喜: 九大農学芸誌, 23, 33 (1967)

14) Magee, W.E. and Burris, R. H. : Am. J. Bot., 41, 777 (1954)

15) Omura, H. and Osajima, Y.: Agr. Biol. Chem., 25, 487 (1961)

16）大村浩久, 鳥巣隆雄, 篠原和毅, 飯尾雅嘉, 井上 義人：未発表

(昭和 46 年 6 月 28 日受理) 